\title{
PENGARUH GCG DAN CSR TERHADAP MANAJEMEN LABA SERTA DAMPAKNYA PADA TAX AVOIDANCE
}

\author{
Rahmawati $^{1^{*}}$, Ida Adhani ${ }^{2}$ \\ Universitas Muhammadiyah Berau, Sekolah Tinggi Ilmu Ekonomi Bhakti Pembangunan \\ rahma.abyalia@gmail.com, adhani.dha@stiebp.ac.id
}

*Corresponding Author

Submitted: 30 Juni 2021

Accepted: 6 Juli 2021

Published: 1 Januari 2022

\begin{abstract}
This study discusses analyzing and obtaining empirical evidence regarding Good Corporate Governance, and Corporate Social Responsibility regarding earnings management and its impact on Tax Avoidance. This study uses research samples published on the Indonesia Stock Exchange for the period 2013-2017. Hypothesis testing using the Partial Least Square method using Smart PLS 3.0 software. The results showed that corporate social responsibility has a positive effect on earnings management, corporate governance contributes to tax avoidance, earnings management is able to mediate the significant influence of good corporate governance on tax avoidance with a positive direction, and management earnings mediate social responsibility that is not significant towards tax avoidance in a positive direction.
\end{abstract}

\section{Keywords: GCG, CSR, EM and TA}

\section{PENDAHULUAN}

Pajak merupakan kontribusi wajib orang pribadi atau badan sebagai wajib pajak kepada negara yang terutang dan tidak mendapat timbal balik secara langsung (kontraprestas), sifatnya dapat dipaksakan, dan pemungutannya berdasarkan undang - undang. Pemerintah menggunakan pajak dalam melaksanakan pembangunan nasioal untuk rangka mencapai kesejahteraan umum diberbagai sektor kehidupan. Wajib pajak di Indonesia dibagi dua, yaitu wajib pajak orang pribadi dan wajib pajak badan. Menurut Rochmat Soemitro yang di kutip oleh Mardiasmo (2011 : 1) Pajak adalah iuran rakyat kepada Kas Negara berdasarkan undang-undang (yang dapat dipaksakan) dengan tidak mendapat jasa timbal (kontra prestasi) yang langsung dapat ditunjukkan dan yang digunakan untuk membayar pengeluaran umum. Definisi pajak tersebut dikoreksi menjadi sebagai berikut, pajak adalah peralihan kekayaan dari rakyat kepada Negara untuk membiayai pengeluaran rutin dan surplusnya digunakan untuk public saving yang merupakan sumber utama untuk membiayai public investment.

Perusahaan dalam melakukan tindakan manajemen laba dan hubungannya dengan penghindaran perpajakan dapat dipengaruhi oleh beberapa faktor, salah satu faktor penyebab terjadinya manajemen laba dan penghindaran pajak (tax avoidance) dan adalah Good Corporate Governance, Corporate Social Responsibility.

Berdasarkan uraian latar belakang tersebut, maka masalah yang diteliti akan dirumuskan sebagai berikut : apakah Good Corporate Governace dan Corporate Social Responsibility (CSR) mempengaruhi praktik manajemen laba, dan memberi dampak pada tax avoidance. Sedangkan tujuan dari penelitian ini adalah untuk membuktikan tentang pengaruh Good Corporate Governace dan Corporate Social Responsibility (CSR)), terhadap manajemen laba pajak serta dampaknya pada penghindaran pajak. 


\section{Penelitian Terdahulu}

\section{STUDI LITERATUR}

Berkaitan dengan topik yang diambil, berikut ini terdapat ringkasan dari hasil penelitian sebelumnya, yaitu:

Egbunike Amaechi Patrick et all (2015) adalah The Influence of Corporate Governance on Earnings Management Practices: A Study of Some Selected Quoted Companies in Nigeria. Objek penelitiannya adalah 33 Perusahaan di Bursa Efek Nigeria selama tahun 2013. Teknik penelitian data menggunakan Regresi sederhana. Hasil penelitian mengungkapkan bahwa Temuan penelitian menunjukkan bahwa praktik tata kelola perusahaan seperti ukuran dewan, ukuran perusahaan, independensi dewan, dan kekuatan komite audit memiliki pengaruh signifikan terhadap praktik manajemen laba di antara perusahaan-perusahaan yang dikutip di Nigeria

Judul Mohammed Amidu et all (2016) adalah Do Firms Manage Earnings And Avoid TaxFor Corporate Social Responsibility?. Objek penelitiannya adalah 119 perusahaan selama periode empat tahun, 2010 hingga 2013 di Ghana. Teknik penelitian data menggunakan metode momen (GMM) dan regresi logistik. Hasil penelitian mengungkapan bahwa hampir semua perusahaan sampel telah terlibat dalam beberapa manajemen pendapatan dan Pajak mereka selama periode tersebut. Studi ini juga menemukan bukti bahwa peningkatan kegiatan CSR dikaitkan dengan peningkatan EM, menunjukkan bahwa, perusahaan sampel dapat menggunakan CSR sebagai kedok untuk terlibat dalam perilaku oportunistik seperti manajemen laba.

Judul Agustine Dwianika (2018) adalah The Effect Of Corporate Social Responsibility Disclosure And Corporate Characteristics Towards Tax Avoidance With Independent Board Of Commissioners As Moderating Variable. Objek penelitian yang digunakan adalah Perusahaan dalam kategori LQ45 selama tahun pengamatan 2014 hingga 2016. Teknik penelitian data menggunakan metode Partial Least Square (PLS). Hasil penelitian menunjukkan bahwa Corporate Social Responsibility tidak berpengaruh signifikan terhadap Penghindaran Pajak dengan nilai 0,164. Ukuran berpengaruh signifikan terhadap Penghindaran Pajak dengan nilai 0,001. Leverage tidak berpengaruh signifikan terhadap Penghindaran Pajak dengan nilai 0,065. Intensitas modal tidak berpengaruh signifikan terhadap Penghindaran Pajak dengan nilai 0,089. Sedangkan secara simultan Corporate Social Responsibility, Ukuran, Leverage, dan Intensitas Modal berpengaruh signifikan terhadap Penghindaran Pajak dengan Independen BOC sebagai Variabel Moderasi dengan nilai 0,000 . Untuk studi selanjutnya dapat mengubah sampel, variabel independen dan penghindaran pajak proksi atau karakteristik perusahaan.

\section{A. Good Corporate Governance}

Pada penelitian ini perhitungan Good Corporate Governance di proksikan dengan Kepemilikan Manajerial, Komisaris Independen, Kepemilikan Intitusional, Ukuran Dewan Komisaris, Komite Audit.

Ukuran Dewan Komisaris = Jumlah Anggota Dewan Komisaris

Sumber : (Setyarini, 2011)

Ukuran Dewan Direksi = Jumlah Dewan Direksi

Sumber : Effendi (2016)

Komite Audit $=$ Jumlah Komite Audit

Sumber : Pujiningsih (2011) 
Owner: Riset \& Jurnal Akuntansi

e -ISSN : 2548-9224 |p-ISSN : 2548-7507

Volume 6 Nomor 1, Januari 2022

B. Corporate Social Responsibility

Pada penelitian ini perhitungan Corporate Social Responsibility di proksikan dengan GRI 4 sebagai berikut :

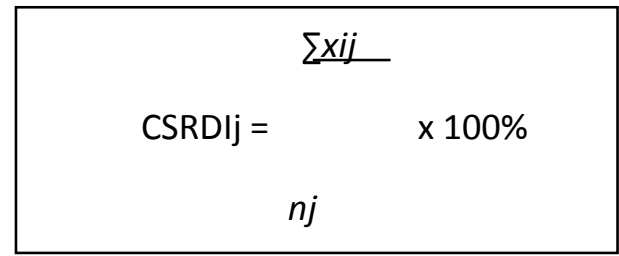

sumber: GRI

\section{Manajemen Laba}

Manajemen laba adalah pemilihan kebijakan akuntansi oleh manajer untuk mencapai tujuan khusus. Pengukuran manajemen laba menggunakan discretinary accrual (DTA) adalah:

1. Menghitung nilai total akrual (TA) yang merupakan selisih dari pendapatan bersih (net income) dengan arus kas operasi untuk setiap perusahaan dan setiap tahun pengamatan.

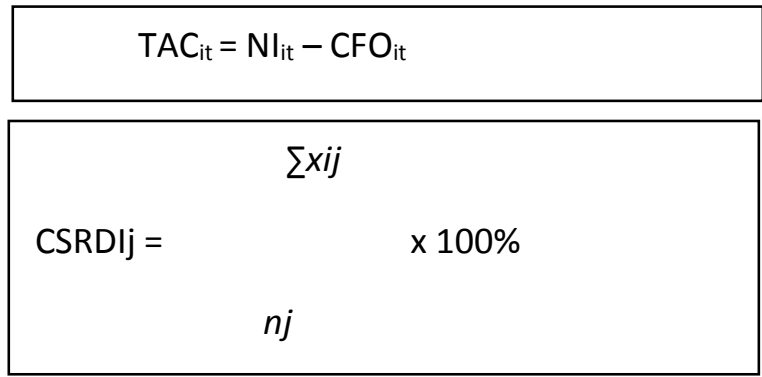

Sumber: Sri Suliyanto (2008)

2. Menghitung nilai accruals

Current Accruals $=\mathrm{D}$ (current assets - cash) $-\mathrm{D}$ (current liabilities- current maturity of long term debt)

Sumber: Sri Suliyanto (2008)

3. Menghitung nondiscretionary accruals model (NDA) adalah sebagai berikut:

$\mathrm{NDAC}_{\mathrm{t}}=\mathrm{TAC}_{\mathrm{t}-1}$

Sumber: Sri Suliyanto (2008)

\section{Tax Avoidance}

Tax avoidance adalah upaya penghindaran beban pajak namun tidak melanggar undangundang yang ada. Cara pengukuran tax avoidance yaitu:

\section{GAAP ETR}

Total income Tax expense

Total pre-Tax accounting income 
Owner: Riset \& Jurnal Akuntansi

e-ISSN : 2548-9224 |p-ISSN : 2548-7507

Volume 6 Nomor 1, Januari 2022

DOI : https://doi.org/10.33395/owner.v6i1.486

Sumber: Hanlon dan Heitzman (2010)

\section{CURRENT ETR}

\begin{tabular}{|c|}
\hline Current income Tax expense \\
Total pre-Tax accounting income
\end{tabular}

Sumber: Hanlon dan Heitzman (2010)

\section{CASH ETR}

\begin{tabular}{|c|} 
Cah Tax Paid \\
Total pre-Tax accounting income
\end{tabular}

Sumber: Hanlon dan Heitzman (2010)

\section{METODE}

Populasi dalam penelitian ini adalah perusahaan yang telah terdaftar di Bursa Efek Indonesia (BEI) tahun 2013-2017. Sedangkan untuk pemilihan sampel dilakukan dengan teknik purposive sampling, Karena keterbatasan waktu penelitan, sampel dalam penelitian ini adalah perusahaan yang bergerak di sektor pertambangan yang terdaftar di Bursa Efek Indonesia dari tahun 2013-2017. Kriteria pengambilan sampel penelitian adalah sebagai berikut :

Tabel 3.1

Tabel Hasil Penentuan Sample

\begin{tabular}{|l|l|c|}
\hline No & \multicolumn{1}{|c|}{ Kriteria Sampel Penelitian } & Jumlah \\
\hline 1 & $\begin{array}{l}\text { Perusahaan sektor pertambangan yang telah terdaftar di Bursa Efek Indonesia } \\
\text { periode 2013-2017 }\end{array}$ & 45 \\
\hline 2 & $\begin{array}{l}\text { Perusahaan sektor pertambangan yang tidak terdaftar di Bursa Efek Indonesia } \\
\text { berturut-turut dari periode 2013-2017 }\end{array}$ & $(6)$ \\
\hline 3 & $\begin{array}{l}\text { Perusahaan sektorpertambangan yang tidak mempublikasikan secara lengkap } \\
\text { annual report dan laporan auditor periode 2013-2017. }\end{array}$ & $(19)$ \\
\hline & Jumlah perusahaan yang dijadikan sampel dalam penelitian & 20 \\
\hline
\end{tabular}

\subsection{Teknik Pengumpulan Data}

Menurut Silalahi (2015: 420-421), data merupakan bahan penting yang digunakan oleh peneliti untuk menjawab pertanyaan atau menguji hipotesis dan mencapai tujuan penelitian. Pengumpulan sumber data ini dengan menggunakan teknik skunder yaitu mengumpulkan data dari seluruh perusahaan yang terdaftar di BEI . Data sekunder didapat dari laporan keuangan perusahaan yang telah terdaftar di BEI. Teknik ini dilakukan dengan mendowload laporan keuangan annual report perusahaan yang terdaftar di BEI. Data tersebut berupa laporan keuangan dan laporan tahunan perusahaan periode 2013- 2017 dengan tujuan agar hasil penelitian mencerminkan situasi terbaru. Data laporan keuangan diperoleh dari situs resmi BEI di www.idx.co.id dan website perusahaan dan menggunakan 
hasil penelitian sebelumnya (jurnal-jurnal) dan literatur-literatur yang relevan, artikel, majalah televisi dan internet yang terkait dengan penelitian ini.

\title{
3.2 Operasionalisasi Variabel
}

Untuk memperoleh hasil penelitian yang menyeluruh, setiap variabel penelitian diukur menggunakan indikator lebih dari satu. GCG menggunakan dua variabel yaitu kualitas dewan komisaris dan dewan direksi. CSR menggunakan tiga variabel yaitu economic, environtment, dan society. Manajemen laba diukur menggunakan TAC, NDA, dan DA serta Penghindaran pajak diukur menggunakan Current ETR dan GAAP ETR.

3.3 Teknik pengumpulan data

Pengumpulan sumber data ini dengan menggunakan teknik skunder yaitu mengumpulkan data dari seluruh perusahaan yang terdaftar di BEI . Data sekunder diperoleh dari laporan keuangan perusahaan yang terdaftar di BEI. Teknik ini dilakukan dengan mendowload laporan keuangan annual report perusahaan yang terdaftar di BEI Data tersebut berupa laporan keuangan dan laporan tahunan perusahaan periode 2013- 2017 dengan tujuan agar hasil penelitian mencerminkan situasi terbaru. Data tersebut diperoleh dari situs resmi Bursa Efek Indonesia di www.idx.co.id dan website perusahaan dan menggunakan hasil penelitian sebelumnya (jurnal-jurnal) dan literatur-literatur yang relevan, artikel, majalah televisi dan internet yang terkait dengan penelitian ini

\section{HASIL}

\subsection{Skema Model Partial Least Square (PLS)}

Dalam penelitian ini, teknik analisis Partial Least Square (PLS) menggunakan program smartPLS 3.0 dalam pengujian hipotesis. Berikut ini sekema model program PLS yang diujikan:

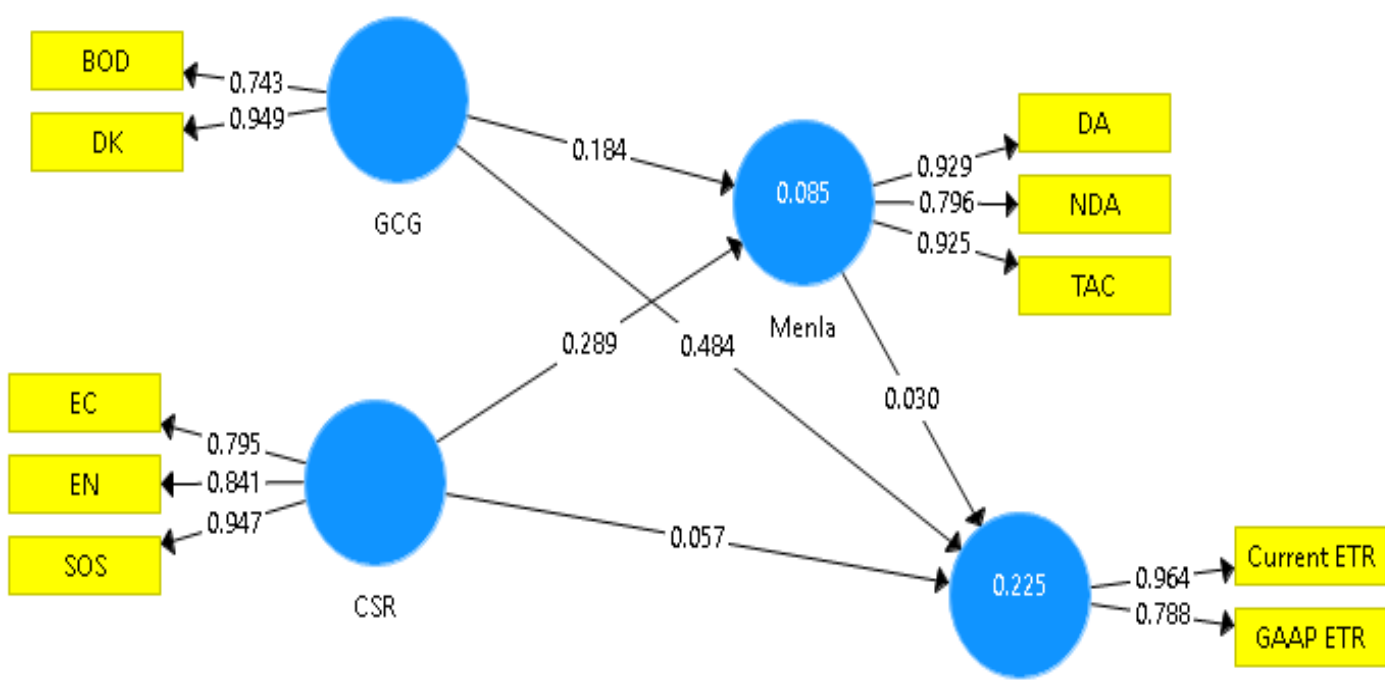

TA

\author{
Gambar 4.1 \\ Outer Model \\ Sumber : Output Smart PLS 3.0
}

4.2 Evaluasi Outer Model

4.2.1 Convergen Validity

Tabel 4.6

Outer Loading 
Owner: Riset \& Jurnal Akuntansi

e-ISSN : 2548-9224 |p-ISSN : 2548-7507

Volume 6 Nomor 1, Januari 2022

DOI : https://doi.org/10.33395/owner.v6i1.486

\begin{tabular}{|l|l|l|l|l|}
\hline & CSR & GCG & MENLA & TA \\
\hline EC & 0,795 & & & \\
\hline EN & 0,841 & & & \\
\hline SOS & 0,947 & & & \\
\hline DK & & 0.743 & & \\
\hline BOD & & 0,949 & & \\
\hline TAC & & & 0,929 & \\
\hline NDA & & & 0,796 & \\
\hline DA & & & 0,929 & \\
\hline Current ETR & & & & 0,964 \\
\hline GAAP ETR & & & & 0,788 \\
\hline
\end{tabular}

Sumber : Output Smart PLS 3.0

Menurut Chin yang dikutip oleh Imam Ghozali, nilai outer loading antara 0,5 - 0,6 sudah dianggap cukup untuk memenuhi syarat convergent validity. Data tersebut menunjukkan tidak ada indikator variabel dengan nilai outer loading di bawah 0,5 , sehingga semua indikator dinyatakan layak atau valid dan dapat digunakan dalam penelitian dan analisis lebih lanjut.

\subsubsection{Discriminant Validity}

Tabel 4.7

\section{Cross Loading}

\begin{tabular}{|l|l|l|l|l|}
\hline & CSR & GCG & MENLA & TA \\
\hline EC & 0,795 & $-0,251$ & 0,224 & 0,076 \\
\hline EN & 0,841 & $-0,291$ & 0,155 & $-0,095$ \\
\hline SOS & 0,947 & $-0,260$ & 0,210 & $-0,052$ \\
\hline DK & $-0,138$ & 0.743 & 0,187 & 0,481 \\
\hline BOD & $-0,557$ & 0,949 & $-0,136$ & 0,273 \\
\hline TAC & 0,163 & 0,030 & 0,929 & 0,034 \\
\hline NDA & 0,131 & $-0,024$ & 0,796 & 0,010 \\
\hline DA & 0,259 & 0,146 & 0,929 & 0,126 \\
\hline Current ETR & $-0,029$ & 0,506 & 0,145 & 0,964 \\
\hline GAAP ETR & $-0,191$ & 0,247 & $-0,066$ & 0,788 \\
\hline
\end{tabular}

Sumber : Output Smart PLS 3.0

Selain mengetahui nilai cross loading, discriminant validity dapat diketahui dengan melihat nilai average variant extracted (AVE) untuk setiap indikator dipersyaratkan dengan nilai > 0,5 untuk model yang baik.

Tabel 4.8

Average Variant Extracted (AVE)

\begin{tabular}{|c|c|}
\hline & Average Variance Extracted (AVE) \\
\hline CSR & $\mathbf{0 , 7 4 5}$ \\
\hline GCG & $\mathbf{0 , 7 2 6}$ \\
\hline TENLA & $\mathbf{0 , 7 8 4}$ \\
\hline
\end{tabular}

Sumber : Output Smart PLS 3.0 
Berdasarkan sajian data dalam tabel 4.8 di atas, diketahui bahwa nilai AVE variabel yang diuji $>0,5$. Berdasarkan tabel diatas dapat dilihat bahwa setiap variabel telah memiliki discriminant validity yang baik.

\subsubsection{Composite Reliability}

Composite Reliability merupakan bagian untuk menguji nilai reliabilitas dari indikatorindikator pada variabel. Suatu variabel dinyatakan memenuhi composite reliability apabila telah memiliki nilai composite reliability $>0,6$. Berikut nilai composite reliability dari setiap variabel yang digunakan pada penelitian ini.

Tabel 4.9

Composite Reliability

\begin{tabular}{|c|c|}
\hline & Composite Reliability \\
\hline CSR & $\mathbf{0 , 8 9 7}$ \\
\hline GCG & $\mathbf{0 , 8 3 9}$ \\
\hline MENLA & $\mathbf{0 , 9 1 6}$ \\
\hline TA & $\mathbf{0 , 8 7 2}$ \\
\hline
\end{tabular}

Sumber : Output Smart PLS 3.0

\subsubsection{Cronbach's Alpha}

Uji realibilitas melalui composite reability di atas diperkuat menggunakan nilai cronbach alpha. Suatu variabel dinyatakan reliabel atau memenuhi cronbach alpha apabila telah memiliki nilai cronbach alpha $>0,7$. Berikut ini adalah nilai cronbach alpha dari setiap variabel:

Tabel 4.10

Cronbach's Alpha

\begin{tabular}{|c|c|}
\hline & Cronbach's Alpha \\
\hline CSR & $\mathbf{0 , 8 2 7}$ \\
\hline GCG & $\mathbf{0 , 7 6 0}$ \\
\hline MENLA & $\mathbf{0 , 8 9 1}$ \\
\hline TA & $\mathbf{0 , 7 4 7}$ \\
\hline
\end{tabular}

Sumber : Output Smart PLS 3.0

\subsection{Evaluasi Inner Model}

Evaluasi model struktural (Inner Model) dilakukan untuk menjawab hipotesis penelitian, sehingga dapat diketahui besarnya pengaruh antara variabel laten. Model struktural adalah model yang menghubungkan variabel laten exogenous dengan variabel laten endogenous atau hubungan variabel endogenous dengan variabel endogenous lainnya. Berikut rangkuman (secara visual) nilai-nilai hasil evaluasi model structural.

\subsubsection{Hierarchical Component Model}

Hierarchical Component Model yang dikenal juga dengan Second Order Confirmatory Analysis (CFA) adalah pengujian melalui dua jenjang, analisis pertama (Weights) dilakukan dari indikator ke variabelnya, analisis kedua (Parsial) dilakukan dari variabel ke kontruk laten lainnya, serta pengaruh secara bersama-sama (Simultan). Hasilnya adalah sebagai berikut:

Tabel 4.11Sub Struktur 1 Hierarchical Component Model (GCG, CSR, Growth--> Manajemen Laba)

\begin{tabular}{|c|c|l|c|c|}
\hline Variabel & Indikator & Weights & Path Coefficients & R Square \\
\hline GCG & BOD & 0.743 & 0,184 & 0,085 \\
\cline { 2 - 3 } (X1) & DK & 0,949 & 0
\end{tabular}


Owner: Riset \& Jurnal Akuntansi

e-ISSN : 2548-9224 |p-ISSN : 2548-7507

Volume 6 Nomor 1, Januari 2022

\begin{tabular}{|l|c|l|l|}
\hline \multirow{2}{*}{$\begin{array}{l}\text { CSR } \\
\text { (X2) }\end{array}$} & EC & 0,795 & \multirow{2}{*}{0,289} \\
\cline { 2 - 3 } & EN & 0,841 & \multirow{2}{*}{0,289} \\
\cline { 2 - 3 } & SOS & 0,947 & \\
\hline
\end{tabular}

Sumber : Smart PLS 3.0

Tabel 4.11 menunjukkan nilai koefisien determinasi ( $R$ Square) pada substruktur adalah $8,5 \%$.

Tabel 4.12

Sub Struktur 2

Hierarchical Component Model (GCG, CSR, Growth, Manajemen Laba--> Tax Avoidance)

\begin{tabular}{|c|c|c|c|c|}
\hline Variabel & Indikator & Weights & Path Coefficients & R Square \\
\hline \multirow{2}{*}{ GCG $(X 1)$} & BOD & 0.743 & \multirow{2}{*}{0,484} & \multirow{8}{*}{0,225} \\
\hline & DK & 0,949 & & \\
\hline \multirow{3}{*}{$\begin{array}{l}\text { CSR } \\
(\mathrm{X} 2)\end{array}$} & $\mathrm{EC}$ & 0,795 & \multirow{3}{*}{0,057} & \\
\hline & EN & 0,841 & & \\
\hline & SOS & 0,947 & & \\
\hline \multirow{3}{*}{$\begin{array}{l}\text { Manajemen } \\
\text { Laba } \\
\text { (Y) }\end{array}$} & DA & 0,926 & \multirow{3}{*}{0,030} & \\
\hline & NDA & 0,802 & & \\
\hline & DA & 0,929 & & \\
\hline
\end{tabular}

Sumber : Smart PLS 3.0

Tabel 4.12 menunjukkan nilai koefisien determinasi ( $R$ Square) pada substruktur adalah $22,5 \%$.

\subsubsection{Quality Criteria (Model Fit)}

Tujuan dari uji kecocokan model (Model Fit) adalah mengevaluasi secara umum kecocokan atau goodness of fit antara data dengan model. SmartPLS memiliki beberapa ukuran sebagai berikut:

Tabel 4.13

Quality Criteria (Model Fit)

\begin{tabular}{|l|c|c|c|}
\hline \multicolumn{1}{|c|}{ Ukuran } & Hasil & Kriteria & Keterangan \\
\hline SRMR & 0,059 & $<0,08^{\mathrm{a}}$ & Model Fit \\
\hline NFI & 0,918 & $>0,90^{\mathrm{a}}$ & Model Fit \\
\hline rms Theta & 0.028 & $<0,12^{\mathrm{a}}$ & Model Fit \\
\hline
\end{tabular}

a) Henseler et al. (2014)

Sumber: Output SmartPLS

4.3.3 Pengaruh langsung dan tidak langsung

Tabel 4.14

Pengaruh langsung dan tidak langsung

\begin{tabular}{|l|r|r|r|}
\hline \multicolumn{1}{|c|}{ Variabel } & \multicolumn{1}{|c|}{ Direct } & \multicolumn{1}{c|}{ Indirect } & \multicolumn{1}{c|}{ Total Effect } \\
\hline $\begin{array}{l}\text { GCG > Manajemen Laba > Tax } \\
\text { Avoidance }\end{array}$ & 0,020 & 0,758 & 0,958 \\
\hline $\begin{array}{l}\text { CSR > Manajemen Laba > Tax } \\
\text { Avoidance }\end{array}$ & 0,291 & 0,814 & 1,105 \\
\hline
\end{tabular}

Sumber : Diolah Peneliti

Berdasarkan tabel diatas, diperoleh hasil Manajemen Laba mampu memediasi pengaruh GCG terhadap Tax Avoidance dengan nilai direct sebesar 0.020, indirect 0,758, total effect 0,958. Manajemen Laba mampu memediasi pengaruh CSR terhadap Tax Avoidance dengan nilai direct sebesar 0,291, indirect 0,814 total effect 1,105 .

4.3.4 Sistem Persamaan Diagram Jalur

\section{Outer model}


Outer model adalah spesifikasi hubungan antara variabel laten dengan indicatorindikatornya atau dapat disebut outer relation atau measurement model, dan mendefinisikan karakteristik konstruk dengan variabel manifesnya. Model indikator formatif persamaannya dapat ditulis sebagai berikut:

$$
\begin{array}{ll}
\text { GCG } & =0,743 \mathrm{BOD}+0,949 \mathrm{DK}+\varepsilon \\
\text { CSR } & =0,795 \mathrm{EC}+0,841 \mathrm{EN}+0,947 \mathrm{SOS}+\varepsilon \\
\text { MENLA } & =0,929 \mathrm{DA}+0,796 \mathrm{NDA}+0,922 \mathrm{TAC}+\varepsilon \\
\text { TA } & =0,964 \mathrm{CurrentETR}+0,788 \mathrm{GAAPETR}+\varepsilon
\end{array}
$$

\section{Inner model}

Inner model, yaitu spesifikasi hubungan antar variabel laten (structural model), disebut juga dengan inner relation, menggambarkan hubungan antar variabel laten berdasarkan teori substansif penelitian. Tanpa kehilangan sifat umumnya, diasumsikan bahwa variabel laten dan indikator atau variabel. Model indikator formatif persamaannya dapat ditulis sebagai berikut:

Manajemen laba $=0,184 \mathrm{GCG}+0,289 \mathrm{CSR}+\varepsilon$

Tax avoidance $=0,484 \mathrm{GCG}+0,057 \mathrm{CSR}+0,030 \mathrm{Menla}+\varepsilon$

\begin{tabular}{|c|c|c|c|}
\hline Jalur & $\begin{array}{l}\text { T Statistik } \\
(>1.96)\end{array}$ & $\begin{array}{l}\text { P Values } \\
(<0.05)\end{array}$ & Keterangan \\
\hline \multicolumn{4}{|c|}{ Dari Indikator ke Variabel } \\
\hline BOD <- GCG & 4,778 & 0,000 & Signifikan \\
\hline Current ETR <- TA & 33,292 & 0,000 & Signifikan \\
\hline DA <- Manajemen Laba & 5,623 & 0,000 & Signifikan \\
\hline DK <- GCG & 12,955 & 0,000 & Signifikan \\
\hline EC $<-$ CSR & 5,313 & 0,000 & Signifikan \\
\hline EN <- CSR & 7,648 & 0,000 & Signifikan \\
\hline GAAP ETR <- TA & 4,024 & 0,000 & Signifikan \\
\hline NDA <- Manajemen Laba & 5,698 & 0,000 & Signifikan \\
\hline SOS <- CSR & 9,030 & 0,000 & Signifikan \\
\hline TAC <- Manajemen Laba & 6,901 & 0,000 & Signifikan \\
\hline \multicolumn{4}{|c|}{ Dari Variabel ke Variabel } \\
\hline CSR -> Manajemen Laba & 2,343 & 0,020 & Signifikan \\
\hline CSR -> TA & 0,538 & 0,591 & Tidak Signifikan \\
\hline GCG -> Manajemen Laba & 1,058 & 0,291 & Tidak Signifikan \\
\hline GCG -> TA & 4,529 & 0,000 & Signifikan \\
\hline Manajemen Laba -> TA & 0,388 & 0,698 & Tidak Signifikan \\
\hline CSR -> Manajemen Laba -> TA & 0,308 & 0,758 & Tidak Signifikan \\
\hline GCG -> Manajemen Laba -> TA & 0,235 & 0,814 & Tidak Signifikan \\
\hline
\end{tabular}

4.4 Uji Hipotesis

Tabel 4.15

Uji Hipotesis

Sumber : Output SmartPLS 3.0 
Tabel menunjukkan bahwa seluruh nilai t-statistik dari indikator ke variabel $>1.96$ dan seluruh nilai $p$-value dari indikator ke variabel $<0.05$, maka dapat disimpulkan bahwa seluruh nilai weights dan loading factors adalah signifikan. Sedangkan nilai t-statistik dan p-value dari variabel ke variabel ada 5 (delapan) yang tidak signifikan, yaitu $C S R$-> TA, GCG-> Manajemen Laba, Manajemen Laba -> TA CSR -> Manajemen Laba -> TA , GCG -> Manajemen Laba -> TA.

\section{PEMBAHASAN}

\subsubsection{Pengaruh GCG terhadap Manajemen Laba}

Hasil pengujian hipotesisi menunjukkan GCG tidak berpengaruh terhadap Manajemen laba, hal ditunjukan dengan nilai T statistik sebesar $(1.058<1,96), P$ Values sebesar $(0,291$ $>0,05)$ dan path koefisiennya sebesar $(0,172)$ yang artinya besar kecilnya Good Corporate Governance tidak mempengaruhi Manajemen laba.

\subsubsection{Pengaruh CSR terhadap Manajemen Laba}

Hasil pengujian hipotesisi menunjukkan CSR berpengaruh positif terhadap Manajemen laba ditunjukan dengan nilai T statistik sebesar $(2.343<1,96), P$ Values sebesar $(0,020>0,05)$ dan path koefisiennya sebesar $(0,289)$ yang artinya besar kecilnya CSR mempengaruhi Manajemen laba.

\subsubsection{Pengaruh GCG terhadap Tax Avoidance}

Hasil uji hipotesis menunjukkan nilai $P$-Values sebesar 0,000 dan mengartikan bahwa GCG berpengaruh positif dan signifikan terhadap Tax Avoidance yang ditunjukan oleh nilai $\mathrm{t}$ statisitik $(4,529>1,96), \mathrm{p}$ values $(0,000<0,05)$ dan path koefisien $(0,484)$, yang artinya besar kecilnya CSR mempengaruhi secara positif terhadap tax avoidance.

\subsubsection{Pengaruh CSR terhadap Tax Avoidance}

Hasil pengujian hipotesis menunjukkan CSR tidak berpengaruh terhadap Tax Avoidance, hal ditunjukan dengan nilai T statistik sebesar $(0,538<1,96), P$ Values sebesar $(0,591>0,05)$ dan path koefisiennya sebesar $(0,57)$ yang artinya besar kecilnya CSR tidak mempengaruhi tax avoidance

\subsubsection{Pengaruh Manajemen Laba terhadap Tax Avoidance}

Hasil pengujian hipotesisi menunjukkan Manajemen laba tidak berpengaruh terhadap Tax Avoidance, hal ditunjukan dengan nilai T statistik sebesar $(0,388<1,96), P$ Values sebesar $(0,698>0,05)$ dan path koefisiennya sebesar $(0,030)$ yang artinya besar kecilnya Manajemen laba tidak mempengaruhi Tax Avoidance.

4.4.6 Pengaruh GCG terhadap Manajemen laba Serta Dampaknya pada Tax Aviodance

Berdasarkan hasil pengujian hipotesis Manajemen laba mampu memediasi pengaruh GCG terhadap Tax Avoidance. Hasill tersebut berdasarkan hasil direct effect $(0,020)$ kemudian ditambah dengan inderect effect $(0,758)$ dihasilkan total efect $(0,958)$. Sehingga bisa disimpulkan GCG berpengaruh positif terhadap manjemen laba melalui tax avoidance.

\subsubsection{Pengaruh CSR terhadap Manajemen laba Serta Dampaknya pada Tax Aviodance}

Berdasarkan hasil pengujian hipotesis Manajemen laba mampu memediasi pengaruh CSR terhadap Tax Avoidance. Hasill tersebut berdasarkan hasil direct effect $(0,291)$ kemudian ditambah dengan inderect effect $(1,105)$ dihasilkan total efect $(1,035)$. Sehingga bisa disimpulkan CSR berpengaruh positif terhadap manjemen laba melalui tax avoidance. CSR adalah tanggung jawab social perusahaan pada masyarakat dalam sektor ekonomi, social dan lingkungan dimana kegiatan tersebut akan mempengaruhi laba dan pajak perusahaan. 


\section{KESIMPULAN}

Good Corporate Governance tidak memiliki pengaruh terhadap Manajemen laba,sedangkan Corporate Social Responsibility memiliki pengaruh terhadap Manajemen laba

Good Corporate Governance memiliki pengaruh terhadap Tax Avoidance, Corporate Social Responsibility tidak memiliki pengaruh terhadap Tax Avoidance.

Manajemen laba mampu memediasi pengaruh yang tidak signifikan GCG dan CSR terhadap Tax Avoidance dengan arah positif,

Penelitian ini terbatas hanya pada sub pertambanganyang dianggap sebagai salahsatu sektor yang ikut menyumbang dalam kerusakan lingkungan sebagai sampel penelitian. Diharapkan penelitian selanjutnya dapat mengambil sektor lain sebagai sampel agar penelitan tentang GCG dan CSR menjadi lebih beragam dan dalam cakupan yang lebih luas.

\section{REFERENCES}

Hanlon, M., \& Heitzman, S. (2010). A review of tax research. Journal of Accounting and Economics, 50(2-3), 127-178. https://doi.org/10.1016/j.jacceco.2010.09.002

Jensen, N., \& Meckling, W. (1976). Theory of the firm: Managerial behavior, agency costs, and capital structure. Journal of Financial Economics.

Mardiasmo. (2016). Perpajakan Edisi Terbaru 2016. In Penerbit ANDI.

Mardiasmo, 2011:7 e siti Kurnia (2010:139). (2011). Pengaruh Pajak penghasilan terhadap kepatuhan wajib pajak. Pengaruh Pajak Penghasilan Terhadap Kepatuhan Wajib Pajak.

Pohan, C. A. (2016). Manajemen Perpajakan Strategi Perencanaan Pajak dan Bisnis. Akarta: PT Gramedia. https://doi.org/10.31294/moneter.v6i1.5353

Santi, D. K., \& Wardani, D. K. (2018). PENGARUH TAX PLANNING, UKURAN PERUSAHAAN, CORPORATE SOCIAL RESPONSIBILITY (CSR) TERHADAP MANAJEMEN LABA. Jurnal Akuntansi, 6(1), 11-24. Retrieved from http://jurnalfe.ustjogja.ac.id/index.php/akuntansi/article/view/536

Scott, W. R. (2015). Financial accounting theory. In Prentice Hall Canada. https://doi.org/10.1016/j.jbiomech.2013.09.028

Silalahi, U. (2000). Metode Penelitian Sosial Kuantitatif. In Journal of Visual Languages \& Computing.

Wardhani, W. M., \& Andono, F. A. (2018). IMPLIKASI TANGGUNG JAWAB SOSIAL DAN LINGKUNGAN TERKAIT POTENSI DUGAAN KEJAHATAN KORPORASI: STUDI CONTENT ANALYSIS PADA PT LAPINDO BRANTAS INC. Jurnal Akuntansi Bisnis. https://doi.org/10.30813/jab.v10i1.987

Kurniasih, L., \& Suranta, S. (2017). Earnings Management, Corporate Governance and Tax Avoidance: The Case in Indonesia. Corporate Governance and Tax Avoidance: The Case in Indonesia (December 9, 2017). J. Fin. Bank. Review, 2(4), 28-35.

Liu, H., \& Lee, H.-A. (2019). The effect of corporate social responsibility on earnings management and tax avoidance in Chinese listed companies. International Journal of Accounting \& Information Management. 
Owner: Riset \& Jurnal Akuntansi

e-ISSN : 2548-9224|p-ISSN : 2548-7507

Volume 6 Nomor 1, Januari 2022

Yorke, S. M., Amidu, M., \& Agyemin-Boateng, C. (2016). The effects of earnings management and corporate tax avoidance on firm value. International Journal of Management Practice, $9(2), 112-131$.

Darmawati, D., Khomsiyah, \& Rahayu, R. . (2004). Hubungan corporate governance dan kinerja perusahaan. Simposium Nasional Akuntansi (SNA) VII. Bali.

GOOD CORPORATE GOVERNANCE DAN PENERAPANNYA DI INDONESIA. (2006). Jurnal Manajemen Dan Wirausaha. https://doi.org/10.9744/jmk.8.1.pp.1-9

Herlambang, S. (2015). Pengaruh Good Corporate Governance Dan Ukuran. Diponegoro Journal of Accounting.

M. Wati, L. (2012). Pengaruh Praktek Good Corporate Governance Terhadap Kinerja Keuangan Perusahaan Di BEI. Jurnal Manajemen, Volume 01, Nomor 01, September 2012.

Retno, R. D., \& Priantinah, D. (2012). PENGARUH GOOD CORPORATE GOVERNANCE DAN PENGUNGKAPAN CORPORATE SOCIAL RESPONSIBILITY TERHADAP NILAI PERUSAHAAN (STUDI EMPIRIS PADA PERUSAHAAN YANG TERDAFTAR DI BURSA EFEK INDONESIA PERIODE 2007-2010). Nominal, Barometer Riset Akuntansi Dan Manajemen. https://doi.org/10.21831/nominal.v1i2.1000 